\title{
Peptide-Catalyzed Asymmetric Epoxidation
}

Organo- and

Biocatalysis

Key words

epoxidation

peptides

aspartic acid

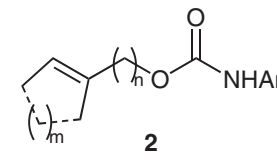

$\mathrm{m}=0,1,2 ; \mathrm{n}=1,2$ $\mathrm{Ar}=\mathrm{Ph}, p-\mathrm{FC}_{6} \mathrm{H}_{4}, p-\mathrm{MeOC}_{6} \mathrm{H}_{4}$
1 (10 mol\%)

DIC (2.0 equiv)

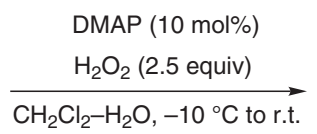

$3.5 \mathrm{~h}-3 \mathrm{~d}$

Selected examples:

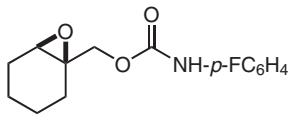

$83 \%$, er $=94.5: 5.5$<smiles>CC1OC1(C)COC(=O)Nc1ccccc1</smiles>

$99 \%$, er $=94.5: 5.5$

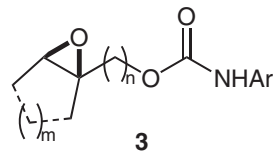

up to $99 \%$, er $=$ up to $96: 4$

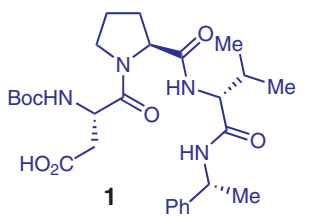

Significance: Peptide $\mathbf{1}$ has been designed as organocatalyst for an asymmetric epoxidation of alkenes 2. Protected allylic alcohols 2 react with aqueous $\mathrm{H}_{2} \mathrm{O}_{2}$ in the presence of chiral aspartate 1 (10 mol\%), DIC, and DMAP to give epoxides 3 in good yields and enantioselectivities. Both cyclic and acyclic precursors can be used. The underlying catalytic cycle presumably involves peracid $\mathbf{4}$ generated in situ from acid $\mathbf{1}$ through carboxyl activation.
Comment: Optically active epoxides are of great practical value, in particular as intermediates for the preparation of enantiomerically pure pharmaceuticals. Recent years have seen the development of various methods for this purpose. In the field of peptide-catalyzed transformations, the Julia-Colonna epoxidation, which requires nucleophilic oxygen donors, represents a prominent example (see review below). In contrast, the oxidant employed in the present approach is electrophilic in nature. An acid-peracid shuttle that exhibits turnover has been unprecedented in asymmetric epoxidation so far. While the substrate scope is currently limited, future improvements of the system can be expected.

Review: D. R. Kelly, S. M. Roberts Biopolymers 2006, 84, 74 . 